\title{
Control of Glyphosate Resistant Hairy Fleabane (Conyza bonariensis) WITH DICAMBA AND 2,4-D
}

\author{
Controle de Buva (Conyza bonariensis) Resistente ao Glyphosate com Dicamba e 2,4-D
}

SOARES, D.J. ${ }^{2}$, OLIVEIRA, W.S. ${ }^{3}$, LÓPEZ-OVEJERO, R.F. ${ }^{3}$ and CHRISTOFFOLETI, P.J. ${ }^{4}$

\begin{abstract}
Auxyn type herbicides such as dicamba and 2,4-D are alternative herbicides that can be used to control glyphosate-resistant hairy fleabane. With the forthcoming possibility of releasing dicamba-resistant and 2,4-D-resistant crops, use of these growth regulator herbicides will likely be an alternative that can be applied to the control of glyphosate resistant hairy fleabane (Conyza bonariensis). The objective of this research was to model the efficacy, through dose-response curves, of glyphosate, 2,4-D, isolated dicamba and glyphosatedicamba combinations to control a brazilian hairy fleabane population resistant to glyphosate. The greenhouse dose-response studies were conducted as a completely randomized experimental design, and the rates used for dose response curve construction were 0, 120, 240, 480, 720 and $960 \mathrm{~g}$ a.i. ha ${ }^{-1}$ for 2,4-D, dicamba and the dicamba combination, with glyphosate at $540 \mathrm{~g}$ a.e. ha-1. The rates for glyphosate alone were 0, 180, 360, 540, 720 and $960 \mathrm{~g}$ a.e. ha ${ }^{-1}$. Herbicides were applied when the plants were in a vegetative stage with 10 to 12 leaves and height between 12 and $15 \mathrm{~cm}$. Hairy fleabane had low sensitivity to glyphosate, with poor control even at the $960 \mathrm{~g}$ a.e. ha- ${ }^{-1}$ rate. Dicamba and 2,4-D were effective in controlling the studied hairy fleabane. Hairy fleabane responds differently to 2,4-D and dicamba. The combination of glyphosate and dicamba was not antagonistic to hairy fleabane control, and glyphosate may cause an additive effect on the control, despite the population resistance.
\end{abstract}

Keywords: Conyza bonariensis, dose-response, glyphosate-resistant hairy fleabane, weed resistance.

RESUMO - Os herbicidas mimetizadores de auxinas como dicamba e 2, 4-D são alternativas parao controle de buva resistente ao glyphosate. Com a possivel futura liberação comercial de culturas resistentes ao dicamba e 2, 4-D, a aplicação destes herbicidas reguladores de crescimento será uma provável alternativa de controle de buva resistente ao glyphosate. O objetivo desta pesquisa foi modelar por meio de curvas de dose-resposta a eficácia do dicamba e 2, 4-D isolados e dicamba em associação com glyphosate para controle de uma população de buva resistente. Um estudo de doseresposta em casa de vegetação foi conduzido em delineamento experimental inteiramente casualizado, sendo que as doses utilizadas para a construção das curvas de dose-resposta foram de 0, 120,

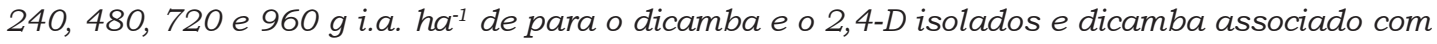
$540 \mathrm{~g}$ e.a. ha $\mathrm{a}^{-1}$ de glyphosate. As doses utilizadas para o glyphosate isolado foram de 0, 180, 360, 540,720 e $960 \mathrm{~g}$ e.a. ha-1. Os tratamentos herbicidas foram aplicados quando as plantas estavam no estádio vegetativo de 10 a 12 folhas e altura entre 12 e $15 \mathrm{~cm}$. A buva apresentou baixa sensibilidade ao glyphosate, pois não foi controlada mesmo na dose de $960 \mathrm{~g}$ e.a. ha ${ }^{-1}$ de glyphosate. O dicambae - 2,4-D foram eficazes no controle da população de buva estudada. A buva responde de forma diferenciada ao 2, 4-D e dicamba e será importante determinar as doses apropriadas de cada herbicida para controle de buva resistente ao glyphosate em condições de campo. A associação de glyphosate e dicamba não foi antagônica no controle da buva e o glyphosate pode causar um efeito aditivo no controle, apesar da resistência da população.

Palavras-chave: Conyza bonariensis, dose-resposta, buva resistente ao glyphosate, resistência de plantas daninhas.

1 Recebido para publicação em 16.9.2011 e aprovado em 25.2.2012.

2 Graduate Student, Plant Science Department, Universidade de São Paulo, Escola Superior de Agricultura "Luiz de Queiroz" ESALQ/USP, 13418-900 Piracicaba, SP, Brazil and Monsanto do Brasil Ltda., 13650-000 Santa Cruz da Palmeiras, SP, Brazil, <daniel.j.soares@monsanto.com>; ${ }^{3}$ Monsanto do Brasil Ltda., 04578-910 São Paulo, SP, Brazil, <wladecir.s.oliveira@monsanto.com, <ramiro.f.ovejero@monsanto.com>. ${ }^{4}$ Associate Professor, ESALQ/USP, Piracicaba, SP, Brazil, <pjchrist@esalq.usp.br> (corresponding author)

Planta Daninha, Viçosa-MG, v. 30, n. 2, p. 401-406, 2012 


\section{INTRODUCTION}

The Conyza species (hairy fleabane, flaxleaf fleabane, horseweed or mare's tale) are rapidly infesting orchards, vineyards, roadsides, canal banks, field crops, and cropless land areas during the autumn/winter seasons throughout Brazil. Normally hairy fleabane infestations in Brazil comprise the coexistence of two species, Conyza canadensis and Conyza bonariensis which present annual or biannual life cycles and adaptation to agro-ecosystems with low mechanical soil disturbance (Moreira et al., 2010). However, the selection of glyphosate resistant Hairy fleabane biotypes has increased over the last years, as a consequence of the over reliance of the main cropping systems on this herbicide (Vargas et al., 2007). Field surveys show that management strategies vary in their ability to reduce the frequency of glyphosate resistance in populations and weed population size, with the most effective being integrated strategies, including alternative weed management and seed set control of surviving plants (Preston et al., 2009).

One or more companion herbicides in sequential application or mixture should also be applied with glyphosate for complete and consistent hairy fleabane control (Damalas \& Eleftherohorinos, 2001). Innumerous papers have been published about the herbicidal alternatives for Hairy fleabane control. Auxin type herbicides, such as 2,4-D and dicamba, are commonly used to control broadleaf weeds in cereals (Nandula \& Manthey, 2002). Since the discovery of 2,4-D in the 1940s, growth regulators have had a critical role in the evolution of agriculture, particularly in weed control (Troyer, 2001). Furthermore, the use of dicamba is highly effective for managing hairy fleabane prior to planting cotton (Gossypium hirsutum) (Steckel et al., 2006).

According to Kruger et al. (2010) the auxyn type herbicides 2,4-D and dicamba are used to control glyphosate-resistant horseweed (Conyza canadensis) before crops are planted. Their research demonstrated that horseweed populations respond differently to the various salts of 2,4-D and dicamba, and it is important to determine the appropriate use rates of each salt to control glyphosate-resistant horseweed.
From the 478 horseweed populations exposed to 2,4-D in the rosette-stage the most tolerant population had $\mathrm{aGR}_{90}$ of $513 \mathrm{~g}$ a.e. ha" ${ }^{1}$, and the most susceptible population had a $\mathrm{GR}_{90}$ of $121 \mathrm{~g}$ a.e. ha" ${ }^{1}$ based on dry weights (Kruger et al., 2008). Growth suppression with 2,4-D was not affected by rosette size if they were between 0.5 and $10 \mathrm{~cm}$ in width. In sorghum, a preplant application of glyphosate at $900 \mathrm{~g}$ e.a. ha $\mathrm{h}^{-1}$ plus 2,4-D amine at $900 \mathrm{~g}$ i.a. ha ${ }^{-1}$ or dicamba at $500 \mathrm{~g}$ i.a. ha ${ }^{1}$ before sorghum planting provided e" $95 \%$ control of hairy fleabane (Conyza bonariensis) (Wu et al., 2010).

Mixing certain chemicals or herbicides with glyphosate has been shown to affect glyphosate efficacy (Kudsk \& Mathiassen, 2005; Koger et al., 2007). O'Sullivan \& O'Donovan (1980) observed that a glyphosate in tank mixture with dicamba and 2,4-D reduced the phytotoxicity of glysophate threshold rates on grasses. With the increasing rates of the herbicides for broadleaved weed control relative to a fixed rate of glyphosate, there was a general trend toward increased antagonism. Increasing glyphosate rates above the threshold level in mixtures containing a fixed rate of herbicides for broadleaved weed control overcame the antagonism. The authors suggested that the reduction in glyphosate plant injury caused by the tank mixing with herbicides such as 2,4$\mathrm{D}$ and dicamba may be due to a physical or chemical incompatibility within the tank mixture rather than the biological interaction within the plant. The objective of this study was to investigate the response of a glyphosate resistant hairy fleabane population to the growth regulator herbicides 2,4-D and dicamba applied at the 10 to 12 -leaf growth stage.

\section{MATERIAL AND METHODS}

A previously tested glyphosate resistant population (data not shown) was selected, and seeds from control plots of this previous assay were harvested and stored in a seed storage room at $10 \mathrm{C}$ prior to study initiation. Seeds were germinated in potting soil in 50 by 25 by $10 \mathrm{~cm}$ white plastic flats in the greenhouse. The growing medium used was composed of a commercial substrate Plantmax ${ }^{\circledR}$. Greenhouse temperatures were kept at 20 to $35^{\circ} \mathrm{C}$. 
Four healthy seedlings were transplanted into an $8.5 \mathrm{~L}$ pot filled with soil from the arable layer of a clay axissol, 16 days after germination. Plants were 0.5 to $1.0 \mathrm{~cm}$ from leaf tip to leaf tip and had three to four leaves at the time of transplanting. Plants were watered daily by drip irrigation. Herbicides were applied when hairy fleabane plants were between 10 to $15 \mathrm{~cm}$ (10 to 12 leaves) in width using a four nozzle boom pressurized by $\mathrm{CO}_{2}$, spaced $50 \mathrm{~cm}$ with a TT1 10015 flat fan nozzle tip, a $120 \mathrm{~L} \mathrm{ha}^{-1}$ carrier volume and a pressure of $275 \mathrm{kPa}$. The three herbicides studied were glyphosate isopropylamine salt, 2,4 D amine salt and dicamba dimethylamine salt. The rates evaluated were 180, 360, 540, 720 and 960 g a.e. ha ${ }^{-1}$ of glyphosate; 120, 240, 480, 720 and $960 \mathrm{~g}$ i.a. ha ${ }^{-1}$ of dicamba isolated or combined with a fixed rate of glyphosate (540 a.e. ha $\mathrm{h}^{-1}$ ); 120, 240, 480, 720 and 960 g i.a. ha ${ }^{-1}$ of 2,4-D amine, and a control without herbicide application.

The experiment was conducted as a completely randomized experimental design. Injury observed in the visual ratings was determined at $7,14,21,28,35$ and 42 days after herbicide application (DAA), with $0 \%$ being attributed when no phytotoxic effect was observed and $100 \%$ when plants were killed. Results are shown only at 35 DAA, since it better represents the average results. At 42 DAA, the plants from each pot were cut at soil level and placed in paper bags and dried in an air circulation oven at $65-70 \mathrm{C}$ until constant weight, in order to determine the dry biomass. The data set was submitted to variance analysis for $F$ test significance and then analyzed employing a nonlinear regression model using the SAS package. A nonlinear regression model was fitted to data with the drc package in R4 (Knezevic et al., 2007). Doseresponse models were constructed using Equation 1.

$$
y=\frac{a}{1+\exp (c(\log (x)-\log (b)))}
$$

In this three-parameter logistic model, $a$ is the upper limit of the model; $b$ is the dose corresponding to the midpoint of plant growth or control response observed between the upper and lower limits; $c$ is the curve slope, $\mathrm{x}$ is the herbicide rate, and $\mathrm{y}$ is the plant response (plant growth or visual injury) - the dry biomass per plant in grams or expressed as percentage of the control $(\%)$. Growth reduction for dry weights and percent of the untreated control were calculated as $\mathrm{GR}_{50}$ and $\mathrm{GR}_{90}$, indicating a 50 or $90 \%$ decrease in the growth of plants. Injury observed in the visual ratings was expressed as percentage of the control, where $\mathrm{C}_{50 \mathrm{~s}}$ and $\mathrm{C}_{90 \mathrm{~s}}$ represented 50 and 90\% visual injury, respectively.

\section{RESULTS AND DISCUSSION}

The $\mathrm{C}_{50}$ value (Table 1 ) in the doseresponse curves for the control (\%) indicates that the glyphosate resistant Hairy fleabane population is more susceptible to dicamba $\left(C_{50}=226.412 \mathrm{~g}\right.$ a.i. ha $\left.{ }^{-1}\right)$ than 2,4-D $\left(C_{50}=320.318 \mathrm{~g}\right.$ a.i. $\left.\mathrm{ha}^{-1}\right)$ and that the combination with glyphosate increased the Hairy fleabane's susceptibility to dicamba $\left(\mathrm{C}_{50}=194.224 \mathrm{~g}\right.$ a.i. $\left.\mathrm{ha}^{-1}\right)$. A dose-response curve for glyphosate alone is not presented because the maximum control obtained was $5 \%$ at the highest rate, and the model used in this research to calculate the dose-response

Table 1 - Dose-response curve regression parameter estimates for \% control of the Hairy fleabane population in response to herbicides at 35 days after application

\begin{tabular}{|l|c|c|c|c|c|}
\hline \multirow{2}{*}{ Herbicide } & \multicolumn{5}{c|}{ Regression parameters } \\
\cline { 2 - 6 } & $a$ & $b\left(\mathrm{C}_{50}\right)$ & $c$ & $F$ & $\mathrm{R}^{2}$ \\
\hline 2,4-D & 96.509 & 320.318 & -3.744 & 230.45 & 0.993 \\
\hline Dicamba & 95.245 & 226.412 & -5.716 & 350.61 & 0.996 \\
\hline Dicamba - glyphosate combination (540 g e.a. $\left.\mathrm{ha}^{-1}\right)$ & 99.361 & 194.224 & -8.023 & $7,281.76$ & 0.997 \\
\hline
\end{tabular}

Abbreviations: $\mathrm{GR}_{50}=$ rate of $50 \%$ of growth reduction calculated by parameter $b$ of the dose-response equation; $a$, the upper limit of the model; $c$, relative slope of the curve around the $\mathrm{GR}_{50}$; and $b$, the $\mathrm{GR}_{50} ; \mathrm{F}$ values for the dose-response model; $\mathrm{R}^{2}$ correlation coefficient of the dose-response model. 
Table 2 - Dose-response curve regression parameter estimates for dry biomass (g per plant) of the Hairy fleabane population in response to herbicides, 42 days after application

\begin{tabular}{|l|c|c|c|c|c|}
\hline \multirow{2}{*}{ Herbicide } & \multicolumn{5}{c|}{ Regression parameters } \\
\cline { 2 - 7 } & $a$ & $b\left(\mathrm{GR}_{50}\right)$ & $c$ & $F$ & $\mathrm{R}^{2}$ \\
\hline 2,4-D & 18.777 & 141.537 & 2.503 & 41.79 & 0.965 \\
\hline Dicamba & 18.756 & 127.721 & 2.286 & 50.57 & 0.971 \\
\hline Glyphosate & 18.507 & $1,190.790$ & 0.428 & 7.39 & 0.831 \\
\hline Dicamba -glyphosate combination $\left(540 \mathrm{~g} \mathrm{ha}^{-1}\right.$ of a.e.) & 18.652 & 49.236 & 0.966 & 163.49 & 0.991 \\
\hline
\end{tabular}

Abbreviations: $\mathrm{GR}_{50}=$ rate of $50 \%$ of growth reduction calculated by parameter $b$ of the dose-response equation; $a$, the upper limit of the model; $c$, relative slope of the curve around the $\mathrm{GR}_{50}$; and $b$, the $\mathrm{GR}_{50} ; \mathrm{F}$ values for the dose-response model; $\mathrm{R}^{2}$ correlation coefficient of the dose-response model.

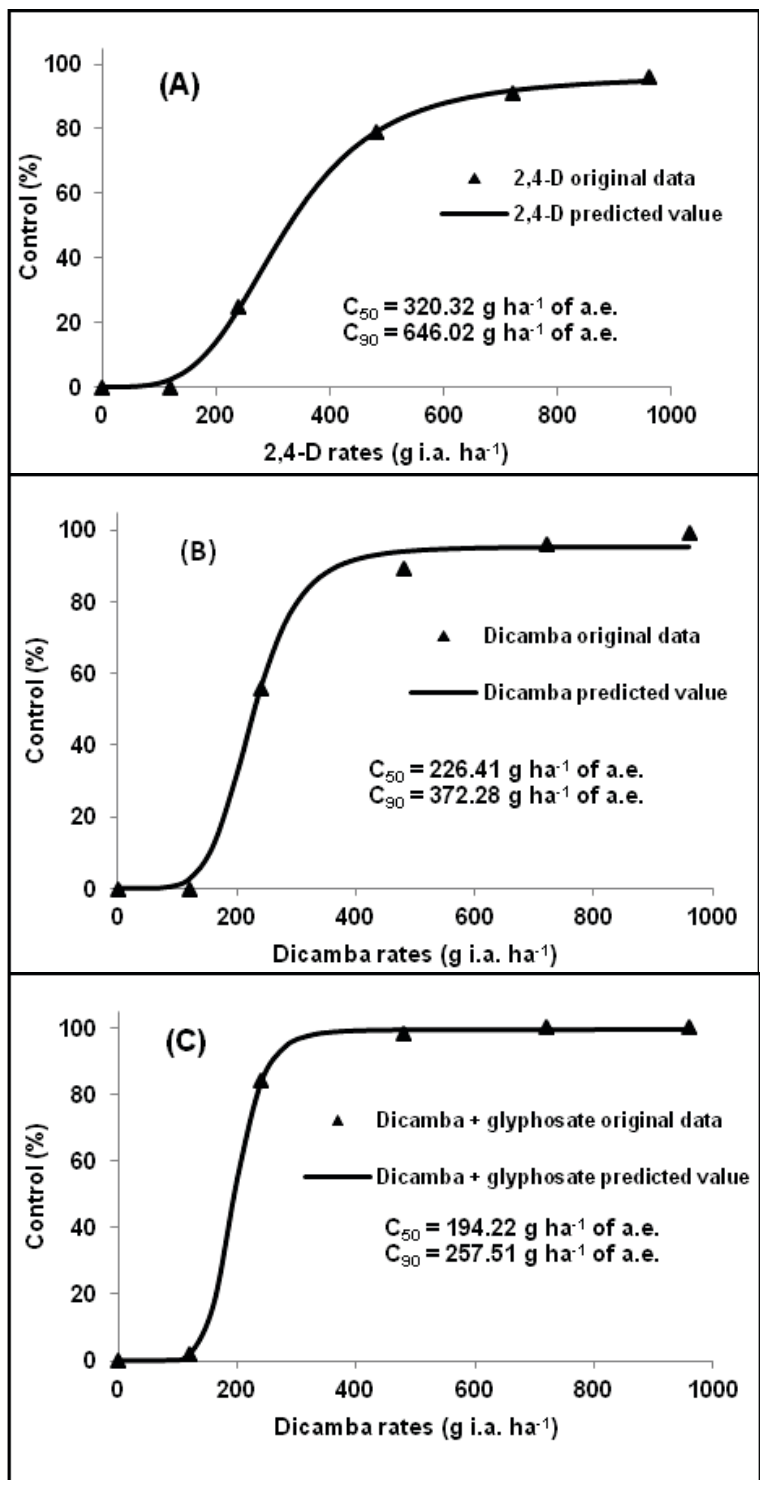

Figure 1 - Dose-response curves of control (\%) of the Hairy fleabane population resistant to glyphosate at $35 \mathrm{DAA}$ in response to varying rates of 2,4-D (A); dicamba (B) and dicamba combined with 540 g a.e. ha-1 of glyphosate (C). requires that a minimum of $50 \%$ control is obtained. These results are confirmed by the $\mathrm{GR}_{50}$ values (Table 2), however the susceptibility of the population to isolated glyphosate is considerably low $\left(\mathrm{GR}_{50}=\right.$ $1,190.79 \mathrm{~g}$ a.e. $\mathrm{ha}^{-1}$ ) which is much higher than the most common field use rate in preplant burndown applications (approximately 560 g a.e. ha ${ }^{-1}$ ). According to Kruger et al. (2010), the dicamba diglycolamine salt provided the highest level of control of glyphosateresistant Hairy fleabane, followed by the dicamba dimethylamine salt, 2,4-D ester and 2,4-D amine, respectively.

Dicamba may play a key role in determining the appropriate post emergence use rates in glyphosate resistant Hairy fleabane. Kruger et al. (2010) suggests that a use rate of 300 to $350 \mathrm{~g}$ a.i. ha ${ }^{-1}$ of dicamba should be considered for control of hairy fleabane, while a 2,4 D ester use rate of $500 \mathrm{~g}$ a.i. $\mathrm{ha}^{-1}$ or more should be considered for control of hairy fleabane. The maximum labeled rate of these two growth regulator herbicides provided greater than $90 \%$ control (Figure 1 and 2) suggesting that these rates are likely suitable for post emergence control of hairy fleabane.

In order to control $90 \%$ of the Hairy fleabane population $646.02 \mathrm{~g}$ a.i. ha $\mathrm{h}^{-1}$ of $2,4-$ $\mathrm{D}$, and $372.28 \mathrm{~g}$ a.i. ha $\mathrm{h}^{-1}$ for dicamba is necessary; however when $540 \mathrm{~g} \mathrm{ha}^{-1}$ of a.e. of glyphosate is combined with dicamba the rate may be reduced to $257.51 \mathrm{~g}$ a.i.ha ${ }^{-1}$. (Figure 1). When this comparison is based on dry biomass this susceptibility difference is not evident (Figure 2). Vargas et al. (2007) tested 2,4-D at $1,005 \mathrm{~g}$ a.i. ha ${ }^{-1}$ to control glyphosate resistant 

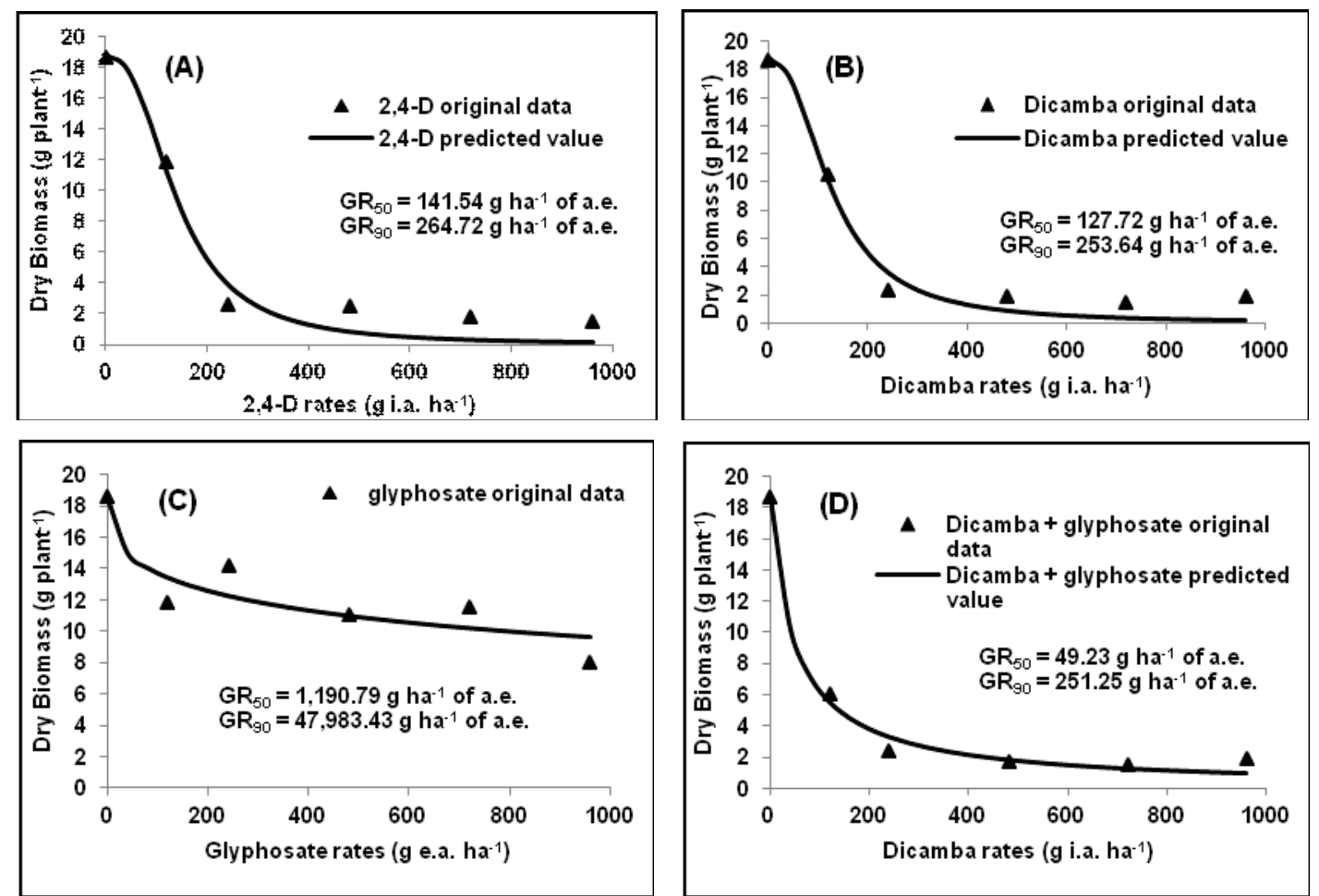

Figure 2 - Dose-response curves of dry biomass (g per plant) of the Hairy fleabane population resistant to glyphosate at 42 DAA in response to varying rates of 2,4-D (A); Dicamba (B); Glyphosate (C) and Dicamba combined with $540 \mathrm{~g}$ a.e. ha-1 of glyphosate (D).

Conyza bonariensis and obtained $95 \%$ control for the resistant biotype and $100 \%$ control for the susceptible biotype, concluding that 2,4-D may be a good alternative herbicide for controlling glyphosate resistant Hairy fleabane at the 4-leaf stage. The most tolerant population of hairy fleabane to 2,4-D studied by Kruger et al. (2008) had a $\mathrm{GR}_{90}$ of $513 \mathrm{~g}$ a.i. ha ${ }^{-1}$, higher than the $\mathrm{GR}_{90}$ obtained in this study.

This research demonstrates that hairy fleabane responds differently to 2,4-D and dicamba. The glyphosate and dicamba combination is not antagonistic to hairy fleabane control and glyphosate may cause an additive effect on the control, despite population resistance.

\section{LITERATURE CITED}

DAMALAS, C. A.; ELEFTHEROHORINOS, I. G. Dicamba and atrazine antagonism on sulfonylurea herbicides used for johnsongrass (Sorghum halepense) control in corn. Weed Technol., v. 15, n. 1, p. 62-67, 2001.
KNEZEVIC, S. Z.; STREIBIG, J. Utilizing R software package for dose response studies: the concept and data analysis. Weed Technol., v. 21, n. 3, p. 840-848, 2007.

KOGER, C. H. et al. MSMA Antagonizes glyphosate and glufosinate efficacy on broadleaf and grass weeds. Weed Technol., v. 21, n. 1, p. 159-163, 2007.

KRUGER, G. R. et al. Response and survival of rosette-stage Horseweed (Conyza canadensis) after exposure to 2,4-D.

Weed Sci., v. 56, n. 5, p. 748-752, 2008.

KRUGER, G. R. et al. Control of Horseweed (Conyza canadensis) with growth regulator herbicides. Weed

Technol., v. 24, n. 4, p. 425-429, 2010.

KUDSK, P.; MATHIASSEN, S. K. Joint action of aminoacid biosynthesys -inhibiting herbicides. Weed Res., v. 44, n. 4, p. 313-322, 2005.

MOREIRA, M. S. et al. Alternative herbicides to control gyphosate-resistant biotypes of Conyza bonariensis and Conyza canadensis. Planta Daninha, v. 28, n. 1, p. 167-175, 2010.

NANDULA, V. K.; MANTHEY, F. A. Response of kochia (Kochia scoparia) inbreds to 2,4-D and dicamba. Weed Technol., v. 16, n. 1, p. 50-54, 2002. 
O'SULLIVAN, P. A.; O’DONOVAN, J. T. Interaction between glyphosate and various herbicides for broadleaved weed control. Weed Res., v. 20, n. 4, p. 255-260, 1980.

PRESTON, C. et al. A decade of glyphosate-resistant Lolim around the world: mechanisms, genes, fitness, and agronomic management. Weed Sci., v. 57, p. 435-441, 2009.

STECKEL, L. E.; CRAIG, C. C.; HAYES, R. M. Glyphosateresistant Horseweed (Conyza canadensis) control with glufosinate prior to planting no-till cotton (Gossypium hirsutum). Weed Technol., v. 20, n. 4, p. 1047-1051, 2006.
TROYER, J. R. In the beginning: the multiple discovery of the first hormone herbicides. Weed Sci., v. 49, n. 2 , p. 290-297, 2001.

VARGAS, L. et al. Conyza bonariensis (L.) Cronq biotypes resistant to glyphosate in southern Brazil. Planta Daninha, v. 25 , n. 3 , p. $573-578,2007$

WU, H.; WALKER, S.; ROBINSON, G.; COOMBES, N. Control of flaxleaf fleabane (Conyza bonariensis (L.) Cronq) in wheat and sorghum. Weed Technol., v. 24, n.2, p. 102-107, 2010. 